Migrant Care Workers at the Intersection of Rural Belonging in Small English Communities

Spiliopoulos, G., Cuban, S., Broadhurst, K.

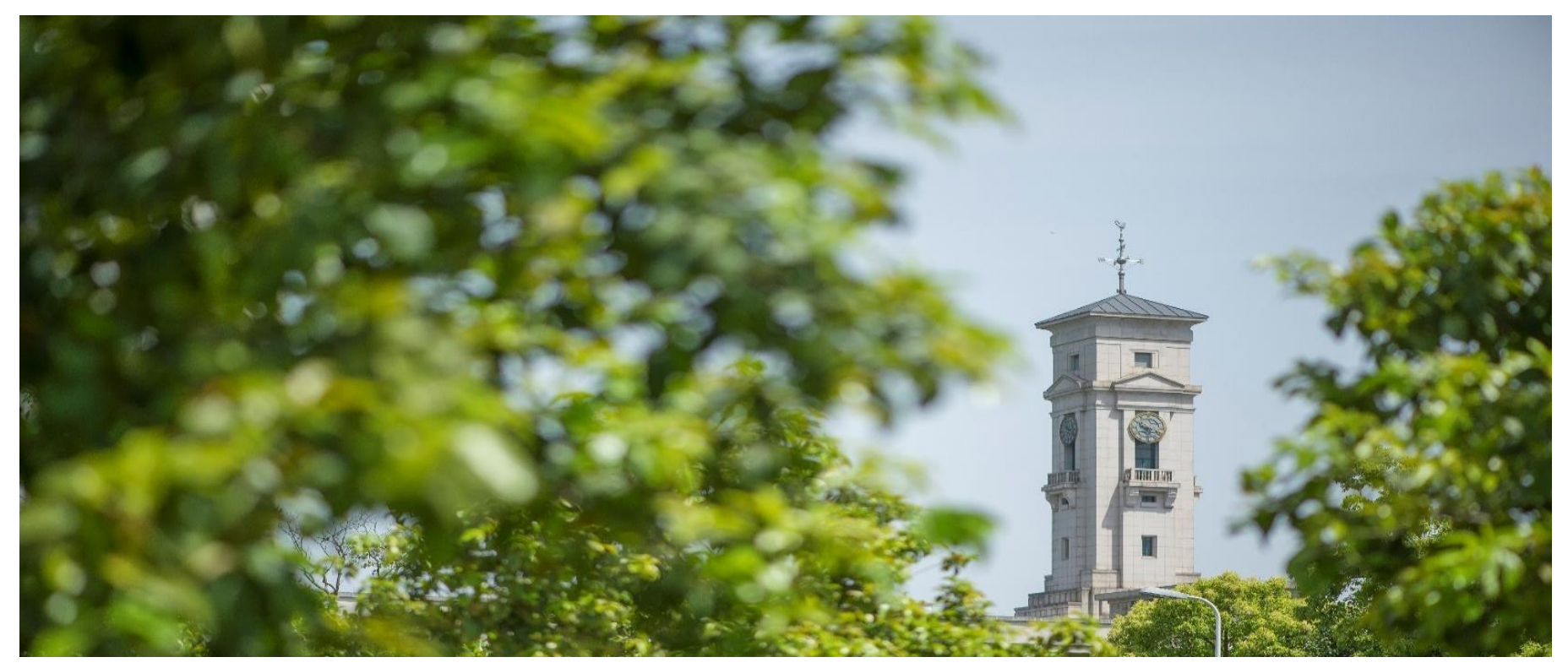


University of Nottingham Ningbo China, 199 Taikang East Road, Ningbo, 315100, Zhejiang, China.

First published 2020

This work is made available under the terms of the Creative Commons Attribution 4.0 International License:

http://creativecommons.org/licenses/by/4.0

The work is licenced to the University of Nottingham Ningbo China under the Global University Publication Licence:

https://www.nottingham.edu.cn/en/library/documents/researchsupport/global-university-publications-licence-2.0.pdf 


\section{Migrant care workers at the intersection of rural belonging in small English communities}

Spiliopoulos Georgia ${ }^{a *}$, Cuban Sondra ${ }^{\mathrm{b}}$ and Broadhurst Karen ${ }^{\mathrm{c}}$

${ }^{a}$ School of International Studies, University of Nottingham Ningbo China, Ningbo,

China; ${ }^{b}$ Department of Health and Community Studies, Woodring College of Education, Western Washington University, Washington, USA; ${ }^{c}$ Department of Sociology, Faculty of Arts and Social Sciences, Lancaster University, Lancaster, UK

Authors:

Dr Georgia Spiliopoulos (corresponding author)

School of International Studies, Faculty of Humanities and Social Sciences, Trent Building, University of Nottingham Ningbo China (UNNC), 199 Taikang East Road, Yinzhou District, Ningbo 315100, Zhejiang Province, China - tel: +86 (0)574 8818 8000, ext. 8063 - orchid-id: https://orcid.org/0000-0002-3430-6951 - email: joy.spiliopoulos@nottingham.edu.cn

Prof Sondra Cuban

Department of Health and Community Studies, Woodring College of Education, Western Washington University, 516 High Street, Bellingham, WA 98225, USA - tel: +1 (360) 650-3000

Prof Karen Broadhurst

Department of Sociology, Faculty of Arts and Social Sciences, FASS Building, Lancaster University, Lancaster, LA1 4YD, Lancashire, U.K. - tel: +44 (0)1524 594126

\section{Abstract}

Shortage of staff in the private care sector brought migrant participants of this study to rural communities in northwest England. The care workers, fourteen highly skilled first-generation migrants, described experiences of feeling unsettled, despite residing in these communities for an average of nine years. Social 
divisions, such as their race, ethnicity, and gender, intersected in rural England to create an overwhelming, at times, feeling of being othered. We use intersectionality as a framework to examine the advantageous and disadvantageous positionings of migrant workers, alongside their strategies of resistance and adaptation, filling in the gaps that acculturation theory glosses over.

Keywords: migrant care workers; rurality; acculturation stress; intersectionality; othering.

\section{Introduction}

This paper examines migrant care workers' strategies of resistance and adaptation in managing acculturation stress in a rural northern English context. Through the lens of intersectionality (Acker, 2006; Anthias, 2013; Walby, 2011; Walby et al., 2012; YuvalDavis, 2006; 2011) the study scrutinizes the unequal positioning of migrant workers in care work settings and more widely in their rural communities, where social divisions of race, gender, ethnicity, and migrancy intersect and shape everyday experience (Acker, 2006; Anthias, 2013; Yuval-Davis, 2006). We argue that the strategies of managing acculturation stress, "being othered" and “claiming ground”, extend Berry’s (1997; 2008) work on acculturation, and offer novel insights into migrant rural settlement.

Participants in this study were nurses, care workers and domestic workers, employed in the private care sector for older adults. The recruitment of migrant health care workers is politically and financially driven (Cangiano et al., 2009; Solano \& Rafferty, 2007; Spiliopoulos and Timmons, 2019; Spiliopoulos, forthcoming) and facilitated through personal networks and recruitment agencies (Cuban, 2013; Yeates, 2009). While in the early 2000 s the highest numbers of migrant nurses were from the Philippines and India (Solano and Rafferty, 2007), the 2004 EU enlargement facilitated the recruitment of Eastern European health professionals, mostly Polish nurses (Jayaweera, 2015). Increased numbers of EU nurses registering with the Nursing 
Midwifery Council (NMC) and then being employed in the UK, corresponded with 2005/6 NHS fiscal policy, which led to cuts to international nurse recruitment (Buchan, 2009), and subsequent preference for hiring EU over non-EU nurses.

The care sector offers migrants few incentives and opportunities for social mobility (Datta et al., 2006), and is characterized by "unstable and insecure employment conditions" and a shortage of labour force (McGregor, 2007, p. 804). Moreover, high turnover of staff (Skills for Care, 2018) is connected to chronic challenges to recruit and retain staff, such as shift and part-time work, low pay and others. Differences in pay reflect regional differences, with the private care sector hourly pay being lower than pay offered by local authority employers (Cangiano et al, 2009). Furthermore, the care sector employs a significant number of migrant workers, with one in six workers having EU or non-EU nationality (approximately 134,000 workers) (Skills for Care, 2018). Importantly, differences in race and ethnicity are overrepresented among social care staff, specifically: Black and British Black staff in direct caregiving; Asian/British-Asian nurses in nursing homes and also BME staff in regions such as London; ethnic minority staff in temporary positions (Cangiano et al., 2009). Other wider, structural factors, which shape care work conditions, are a burgeoning "care deficit", with care offered increasingly by private and third sector providers; and the underfunding of the sector, with then relies on migrant care workers (Cangiano \& Shutes, 2010).

The concept of "inequality regimes" (Acker, 2006) assists in the examination of formal and informal processes in the private care sector which create "systematic disparities" and hierarchical structures. We argue, that although these work environments invite an interrogation of intersection of gender, race, ethnicity, class and other divisions, migrant agency is also operating within these spaces. Importantly, it is in the rural environment---the rural northern English communities---where structural factors impose 
social divisions and which are then embodied as, "contradictory articulations of difference and identity" (Anthias, 2013: 335, emphasis in original).

We begin our examination of how social divisions intersect to create advantageous and disadvantageous positionings in these rural settings by firstly, exploring hidden power relations in the English "rural idyll" and then, by offering theoretical grounding for exploring complex rural belongings. We discuss in some detail the qualitative nature of our research, before presenting the participants' experiences of rural belonging, alongside their strategies of resistance and adaptation. We conclude by offering recommendations for research in an area which invites closer scrutiny of othering processes, for those deemed "non-British", and working in a rural setting and for a highly gendered and at times exploitative sector.

\section{Hidden power relations in the English "idyll" - the "outsiders"}

For Cloke (2004) "the rural" is as an embodied experience, with the agricultural use of land, affiliation with nature and subsequent lifestyle attainment. For others, such as Murdoch and Pratt (1997), in any efforts of defining the "rural", there are hidden power relations and nationalistic connotations of "Englishness" and "English values". Such power relations separate those who ascribe to such values from those who are deemed outsiders. Rural England has been viewed historically as a setting of racial purity, British culture and morality, in contrast to urban settings (Agyeman \& Spooner, 1997). Furthermore, the contentious issue of legitimate rural inhabitants is not a new phenomenon but can be traced in nineteenth century literature with the influx of middleclass families in small villages (Neal \& Agyeman, 2006), and more recently through anxieties over gentrification, the banning of fox hunting and others (Neal \& Walters, 2006). 
It is in this context of nationalist sentiment and anxieties over rural belonging and practices that immigrants become part of the Other. Migrants are mostly faced with exclusion by locals (Cloke \& Little, 1997; Tolia-Kelly, 2007) and face particular difficulties in finding employment, travelling, networking and engaging in familiar social practices, in contrast to their counterparts in urban areas (de Lima, 2006). While authors such as Askins (2009) seek to reconceptualize the English rural as a "transrural", multiethnic space, we argue that such experiences are shaped by structural factors such as opportunities and restrictions for physical and social mobility, historical presence of migrant and ethnic communities, and proximity to major urban centers. Therefore, closer examination of case-by-case English rural communities, through an intersectional approach, is essential.

\section{Complex belongings and othering processes - why examining intersections of social divisions in small rural communities matters}

We begin our discussion by firstly framing migrant rural workers' complex belongings and identifications as key to their intersecting advantageous and disadvantageous positionings. Belonging is conceptualized as an "emotional attachment" relating to the feeling of safety, of being at "home", and is an ongoing project. Importantly, this new "home" is not always a safe space. Belonging is "multi-layered" and "multi-territorial", social and geographical locations shaping belongings (YuvalDavis, 2011). Yuval-Davis (2011) examines belonging through three dimensions: social locations; identifications and emotional attachments; and ethical and political values. Social locations or groupings based on professional identity, race, gender or class, to name but a few, are highly contextualized, can harbor "axes of power", in terms of preferential belonging and exclusion based on such divisions. Identifications or "identity narratives" are constructed as relative to collectivities but are also indicative of individual 
interpretations of self and agency, can be verbal and/or performative (Yuval-Davis, 2011), and are fluid and highly contextual (Fortier, 2000; Hall, 1996). Moreover, they are highly selective - "they can shift and change, be contested and multiple" (YuvalDavis, 2011, p. 14).

A more in-depth examination of belonging based on ethical and political values raises the issue of "boundaries" and how these are monitored and how they defining the parameters of participation and membership, alongside resistance towards such hegemonic structures (Yuval-Davis, 2011). Anthias (2013), in interrogating immigration policies and processes of integration in the UK, eloquently asks how much difference is acceptable and tolerated. The migration system favors the economic benefits that migrant labor brings, while seeking to eradicate cultural, ethnic and religious distinctiveness and impose an assimilative type of integration. Thus, normative and unattainable conceptions of "community" are sustained, creating types of conditional citizenship (Anthias, 2013; Anderson, 2013). This "community of value" (Anderson, 2013, p.13) regulates citizenship and belonging and is based on perceived shared cultural values, such as good neighborly relations, law-abiding, hard-working citizens partaking in community activities, for example, going to the local pub or the local church. Outsiders, therefore, are evaluated by the legitimate ("good") citizens and help define the boundaries of belonging.

Acculturation as an analytical concept is useful in examining intercultural adaptation and belonging through the interchange between majority and minorities (Berry, 1997; 2005; 2008; 2009; Berry \& Sabatier, 2011), in how newcomers settle, adapt, assimilate or reject new culture and surroundings, and any nuances over time. Individuals and groups use different "strategies" to incorporate or reject cultural values and practices (Berry, 1997, pp. 9-10): assimilation, where individuals and groups do not wish to 
continue practicing their own cultural identity, seeking more interaction with other cultures; separation, where newcomers distance themselves from others in the host environment; integration, where cultural identity and traditions are maintained but interaction with other cultures, and a degree of "mutual accommodation" between parties, is also evident; and finally, marginalization, where newcomers reject their own cultural traditions and there is little contact with other cultures in the new environment, especially when discriminated against.

Even though integrating both host and home countries' cultural practices can be a smooth process, '[i]nconsistencies and conflicts between these various acculturation preferences... [can be] common sources of difficulty for those experiencing acculturation" (Berry, 2008, p. 332). Acculturative stress "is defined as one kind of stress in response to life events that are rooted in the process of acculturation, which usually includes psychosocial difficulties (e.g., loss of social support, rejection by the host culture) when adapting to a new culture" (Wu \& Mak, 2012, p.71). Berry (2005) emphasizes that acculturation stress can enclose both positive and negative experiences, for example, improving coping mechanisms (Berry, 1997). Importantly, acculturation stress incorporates the constraints that migrants experience. The "universality" of Berry's acculturation theory (2009) has been criticized for not considering power imbalances (Bhatia \& Ram, 2009; Weinreich, 2009) and structural factors which create different forms of oppression, such as insecure working conditions and "othering" practices, also policy-making, as in the UK the "preferred" mode of integration is assimilation (Anthias, 2013). In trying to close such gaps in acculturation theory, we use an intersectionality approach (Acker, 2006; Anthias, 2013; Walby, 2011; Walby et al., 2012; Yuval-Davis, 2006; 2011). Such an approach assists in the examination of factors pertaining to power relations and which highlight social divisions such as race, class, gender and ethnicity. 
We examine these social divisions intersecting not simply as additive factors, an approach which can "essentialize specific social identities", leading to further marginalization (Yuval-Davis, 2006, p.205). We place significant importance on how these social divisions intersected in the English rural "idyll" as ontological entities (Walby, 2011), shaping each other in a dynamic way (Walby et al., 2012) and in a particular place/time contexts (Yuval-Davis, 2006; 2011).

We discuss privileges and disadvantages that are products of specific structural inequalities. Acker's (2006, p. 441) concept of "inequality regimes", allows for an examination of "the interlocked practices and processes that result in continuing inequalities in all work organizations... [as] critical locations for the continuous creation of complex inequalities". In our study, the private care homes were the "critical locations" where advantages, disadvantages and tensions shaped the migrant care workers' positioning in rural northern England. The care homes grounded the participants in these communities but did not always provide a sense of "safety" or mitigate feelings of being unsettled. We examine, thus, the everyday experiences of living in these rural communities, where the care homes were located, as intersections of social divisions caused differential types of inequality and oppression between locations (Anthias, 2013; Yuval-Davis, 2006; 2011). Furthermore, structural inequalities in the form of differentiation of criteria for professional recognition in the UK between EU and non-EU nurses provide such an example of "hegemonic political powers" (Yuval-Davis, 2011) which create particular advantages and disadvantages (Spiliopoulos and Timmons, 2019). The Nursing and Midwifery Council (NMC) regulates professional standards and adaptation programs for nurses trained outside Britain, in connection to professional skills and language attainment. The NMC, until recently, placed more stringent rules on nonEU nurses, for example, Filipino nurses who have high level of English language 
proficiency (Kingma, 2006), in comparison to EU nurses who until 2017 were not subjected to English language testing (Lintern, 2017; NMC, 2017). Such practices favor specific nationalities on the basis of politically and financially driven policymaking (Spiliopoulos and Timmons, 2019; Spiliopoulos, forthcoming).

\section{Research design}

The fourteen migrant care workers in this study were living in two rural locations: a rural and a semi-rural area. The majority were nurses, mainly from the Philippines and India, also Poland, with a smaller number of care and domestic staff from Thailand, Cuba and Egypt (Table 1). Access to the sites was made possible through an ESRC-funded project ${ }^{1}$. Community $\mathrm{A}$ is a small town with a population of approximately seventy thousand, with surrounding natural beauty. It is at significant geographic distance from other, large and multicultural cities and also transport routes such as motorways and airports, while all participants in this community experienced it as lacking cultural diversity. Even though ethnic diversity is represented through non-English languages spoken---Polish, languages from China, and Tagalog---, it has a smaller than the national average non-British population, approximately three per cent ${ }^{2}$, lower than the average estimate of eight per cent across the UK (Migration Observatory, 2012). Finally, due to

${ }^{1}$ Cuban S. (principal investigator). (2010). "Home/Work: The Roles of Education, Literacy, and Learning in the Social Networks and Mobility of Migrant Carers." ESRC project, Department of Educational Research, Lancaster University, 2008-2010.

2 'People and Society: Population and Migration', Neighbourhood Statistics, Office for National Statistics, www.neighbourhood.statistics.gov.uk (26/06/2013) - the exact webpage is not offered here in order to protect the anonymity of the participants. 
its declining economy and high levels of deprivation, employment offered in Community $\mathrm{A}$ is in the following sectors: manufacturing, retail trade, and health and social care.

Community B has a much smaller population of about five thousand inhabitants and is more isolated than Community $\mathrm{A}$, lacking a railway station and being reliant on its road infrastructure, making travelling made arduous in the harsh winter months. Historically, the local economy was reliant on mining and wool industries, while in recent years it relies primarily on tourism. Like Community A, it has a smaller than the national average percentage of migrants, employed mainly in the hospitality sector and being predominately white European. The private care sector as an important employer is due to recent influx of an older population retiring in the area, as half of its population was over the age of 50 in $2011^{3}$.

The main data collection methods were in-depth, semi-structured interviews, combined with ethnographic observations. Data collection took place weekly between March 2008 and April 2009, and forty-two interviews, three with each participant, were conducted, average time of interviewing being one hour, in person or over the phone. Ethnographic observations, a total of fifty-six hours, took place in: four nursing and one residential home; one ethnic store; one library; and the care workers' private homes, including invitations to family meals and to one child's birthday party. The first interview with each of the participants was a biographical interview, the second and third

${ }^{3}$ Information derives from the 'Resident Population Estimates by Broad Age Band (2001-2011)', People and Society: Population and Migration, Neighbourhood Statistics, Office for National Statistics for the ward of Community B (accessed on 26/06/2013). The exact website is not offered to protect the participants' anonymity, as the percentages of ethnic minorities in Community B are very small and individuals could be easily identifiable. 
interviews, however, had a more empowering character (Heyl, 2001) as participants were encouraged to narrate on their experiences.

As feminist researchers and ethnographers, conscious effort was made to avoid "essentializing" social divides which would replicate, unintentionally, social stratification. This was done, for example, by using personal reflection diaries and constructive dialogue between us. Visible characteristics such as our gender and race (female, white Caucasian) were not shared by all participants. But our positioning in the field, in fact, went "beyond the insider-outsider divide", closer to an "insider by proxy" position (Carling, et al., 2014) due to common ground in experiences, such as migratory movements, employment in the social care sector, being main "breadwinners" and having young children. Such common ground facilitated communication and the building of trust with the participants over the period of one year (2008-2009).

Two methods of analysis were employed, thematic (Aguinaldo, 2012; Boyatzis, 1998) and narrative (Labov, 1984; 2003; 2010; Labov \& Waletzky, 2003; Mishler, 1986; 1990; 1999; Riessman, 1987; 1993; 2000). Thematic analysis (Aguinaldo, 2012; Boyatzis, 1998) was used to examine the patterns and broader themes emerging from the interview transcripts and commonalities between a disparate group of first-generation migrant care workers in these isolated, rural communities. Narrative analysis allowed for more in-depth examination of rural settlement with its specific to their social divisions experiences of oppression. Moreover, the combination of different narrative analysis approaches created a unique blend of interpretive practice. Riessman's (1987; 1993; 2000) construction and performance of identity through narratives; Labov's (1984; 2003; 2010; Labov \& Waletzky, 2003) textual analysis of narratives of personal experience, especially locating the "complicating action" and "resolution" in a narrative; and Mishler's $(1986 ; 1990 ; 1999)$ structural analysis of personal experiences in narrative 
episodes, narrator's agency and his focus on the production of narratives as "socially situated actions" (Mishler, 1999), were approaches combined in order to analyze the identifications, complex belongings, interpretations and resolutions.

We focus on the most prominent themes that emerged from thematic analysis. "Being othered" and "claiming ground" are strategies used to cope with acculturation stress intensified through pressures to assimilate and processes of othering. Narrative analysis revealed the related tensions and efforts to reconcile contradictory positionings

- "being othered" and "claiming ground - and to manage acculturation stress. Other themes emerged, reflecting the participants' complex belongings and acculturation stress - "managing an 'ideal migrant' image" and "finding an authentic voice"; "isolation" and "bonding"; "escaping" and "rooting" - but go beyond the scope of this paper.

\section{“Claiming ground" while experiencing everyday "othering” processes}

The overwhelming majority of participants related stories of discrimination in their social and professional life in both communities A and B. "Claiming ground" was a strategy which could help overcome isolation and exclusion by networking with local residents, participating in local events and using local services, thus helping to create a sense of belonging to the area. The majority of networks established were with kin, in other areas in the UK and with ethnic communities. Networks with local English people were less frequent and connected to their employment. Arguably, "claiming ground" is an active way of dealing with "being othered". However, "being othered" invites reflection, the narrating of experiences allowing for "unfolding reflective awareness" (Ochs \& Capps, 1996, p. 21), and can instigate action. In this section we delve deeper into the analysis of how "othering" was experienced and strategies of resistance and adaptation towards rural settlement. 


\section{The challenges of "claiming ground" in rural settings - the cases of Munir and}

Niall

Thematic analysis (Aguinaldo, 2012; Boyatzis, 1998) revealed different forms of "othering", experienced as exclusion, discrimination and exploitation, in the workplace and in public spaces. "Claiming ground" may not have always been possible, showcasing how social divisions were exacerbated in these "critical locations", the care homes, and rural settings.

Niall, a Filipino male care worker, and Munir, an Egyptian male care worker, resided in Community $\mathrm{A}$ and worked for the same private care company. They migrated to the UK as "nurse husbands" (George, 2005): in Niall's case because of his wife, Raquel, being employed as a nurse by the private care company, her migratory move instigating family relocation and his subsequent career change from banker to care worker; in Munir's case, his former Filipino wife, a nurse, encouraged him to move to the UK and to find employment in the care sector, his previous occupation being gym instructor. "Othering" practices were experienced as heightened visibility, their gender, nationality, ethnicity and religious identity intersecting to create different types of belonging and experiences of social exclusion.

In Niall's case, the agents of othering were the elderly residents he cared for: "some English people, their perception of us is like we live in a primitive place back home". He explained that the residents would ask him if his family lives in mud huts in the Philippines, a misconception, when considering that the place of origin, Manila, is a large metropolis. He "claimed ground", by attending his local Catholic church services: "like half of the people inside the church are Filipinos" and socialized with other Filipinos in the community. 
While Niall was Christian and married with children, and had a number of local networks through the local Catholic church, Filipino diasporic community and the children's school, Munir as a single, Egyptian man, was frequently targeted by English locals as a "terrorist" because of his race, gender and age: “[I'm] lonely, not free to go when I want, because it's happened many times to me, stopping me and swearing at me, it happens very often". In an effort to deal with discrimination and abuse, he fantasized about moving to an urban area where he would be less "visible": I have a choice for a job before, supposed to be South London and it was nearly double pay, same I have at the moment, personal carer for only one person. But, for some reason I didn't go, but this just explains for me how good it will be if I'm living in the city. ... maybe there because it's a big city and different kinds of people, different faces, things like this, so nobody will recognize me in the street. But here, it's a small place, walking the streets affects me emotionally, when I get abuse and get nervous.

For Munir, "claiming ground" outside the care home was not an option. In another interview, he disclosed that he would either take a taxi or leave his house with his British girlfriend, a carer in the same care company, avoiding potential confrontation and abuse in public spaces. Such experiences had a debilitating effect in his everyday life, with the care home offering a sense of safety and belonging otherwise absent. Even though both Niall and Munir were living in the same community and working for the same private care company, membership to the "community of value" (Anderson, 2013) and perceptions over race, ethnicity, religious belonging created contextual differences, which were either tolerated or rejected (Anthias, 2013).

Below we provide more in-depth analysis of acculturation stress by presenting narrative episodes (Mishler, 1999) from three participants - Satya, Tristana and Bonnie. 
Narrative "episodes" are chosen from the co-produced "identity performances" (Mishler, 1986; 1999). The narrative extracts combined two narrative episodes - separated by a forward slash -and showcased the "core story" (Mishler, 1999) and conflict experienced by the participants, also oscillation between antithetical positions. These cases are representative of the many complexities faced by the participants in their everyday lives and how they managed surfacing acculturation stress which was directly related to their unequal positioning on the bases of: gender, race, ethnicity, nationality and English language competency.

\section{"They are paying me the carer payment, that's the problem"-Satya's case}

We begin examining narrative episodes of the experiences of "being othered" and "claiming ground" with the example of Satya, an Indian Kerala nurse who arrived in Community B in 2005 through an employment agency in India, an expensive procedure costing five thousand British pounds. When we first met her, she was living in Community B and although she had kin in England, they were at significant geographical distance---her husband, an Indian Kerala social worker, was living in a town three hours' drive away, while her sister, a NHS nurse, was living in a town four hours' drive away. For Satya, the experience of working and living in Community B meant that she successfully obtained recognition as a nurse in the UK. However, she experienced "othering" in the care home in the form of racial discrimination and financial exploitation:

Everybody's been very nice, very nice. The manager is very nice and others, the residents also, alright, no problems with them. And... some old people, they don't like us, they call maybe black people like that... Because of that, maybe they don't like people from black India or from other countries like that. But it's alright, it's not a big... / But [nursing] home... mmm... yes, sometimes I work as a carer. [...] We paid so much money..., I paid to do this adaptation [Overseas Nursing Program] also. So, after I am enrolled, I am doing carer evening, I will get carer payment. Not good but I don't mind to do the carer duty, we are giving care to residents, I don't 
mind, as a nurse, we want to give every day, that's not a problem that we have. When I am doing carer duty, they are paying me the carer payment, that's the problem.

Satya is explaining that her overall experience working at the nursing home was a positive one, "[e]verybody's been very nice" and repeats that she had good relations with her manager and colleagues. Repetitions are "intensifiers" and indicative of the emotional landscape of the narrator (Mishler, 1986), for example, by repeating "very nice" and "alright", Satya is dealing with the uncomfortable feeling of being "othered", "some old people, they don't like us, they call maybe black people like that'. Through narrating, experiences are reconstructed for the benefit of the listener and the narrator's, in dealing with uncomfortable feelings (Riessman, 1993), here by minimizing the othering practices of the elderly residents. Moreover, she endured this discrimination through collegial support. Satya then explains repeatedly, that the experience of working at the nursing home was not as "good" as originally stated, because of financial exploitation from the private nursing home, especially when juxtaposed with the expenses procured for undertaking the Nursing and Midwifery Council (NMC) adaptation program. The dissatisfaction does not stem from her role as a carer per se but is due to the financial exploitation, which was "the [real] problem". Here we see how Satya's race, ethnicity, nationality and precarious working conditions placed her in a "set of unequal relations" (Walby et al., 2012), where the care home as a "critical location" helped buffer discrimination, however perpetuated hierarchical system of oppression in the form of financial exploitation. She "claimed ground" through seeking recognition in the UK as a qualified nurse, albeit with related tensions, "[w]e paid so much money”, and through moving to an urban area, where she gained access to family support and to co-ethnic networks, also opportunities for improved financial compensation. Acculturation stress, seen here in the oscillation between positionings of "being othered" and "claiming 
ground", was experienced because of the intersection of social divisions, such as gender, race, nationality, which placed Satya's in a disadvantaged position. For Satya, the only solution available to her in dealing with financial exploitation and discrimination was to relocate to an urban centre, where she could have close contact with family and access to a more multicultural lifestyle and opportunities for better pay.

\section{“I'm a good worker, because I'm Polish" - Tristana's case}

Tristana, a Polish nurse, arrived in Community A after meeting her English partner in Poland and had been living in this community for six months when first interviewed. She experienced "being othered" in her everyday interactions with her English colleagues, with her English language pronunciation and Polish nationality being emphasized as social divisions but simultaneously celebrated as belonging to a migrant group desirable for employment in the social care sector (post-global financial crisis):

There have been no problems but there will always be difference. People will treat you always differently. They will never respect you like the English.... I experienced that... Like I'm working here few months now and I've done the handover lots of times and the nurse who works once a week, she can't understand me and every five minutes she was asking me 'what is that?' and I thought I can't speak English.... [...] I got one positive thing, when the manager asked me to bring some more Polish nurses here, that was nice.... (company $\mathrm{X}$ ) is looking for nurses and the manager asked me to call some nurses from home and if I've got some friends to come and work. That made me feel little bit like I'm a good worker, because I'm Polish / [In the nursing home on the handover records] I see B.O. (body odor), they never use the full name, they put, they use the short... I ask. Just act silly, "I don't know, what's that?" and then they explain to me... That's one way to learn.

In this narrative episode, Tristana's strong, emotive statement " $[\mathrm{t}]$ hey will never respect you like the English" is indicative of her frustration towards normative expectations of belonging (Anthias, 2013; Anderson, 2013), of not having a more English accent. Her 
narration is performative (Riessman, 2000), her choice of words enables the listener/reader to feel her frustration. In response to her colleague's reaction, she offers a comment that indicates that she internalized othering: "I thought I can't speak English". She then tries to manage this tension by explaining that she is appreciated as a "(Polish) worker", her nationality placing her in an advantageous position because of policymaking facilitating the hiring of EU nurses over non-EU (Cuban, 2013; Spiliopoulos and Timmons, 2019). Tristana took her manager's comment of her nationality and ethnic networks as validation, much needed to counteract the feeling of not being "respected". In the second extract she tried to overcome these othering practices by "acting silly", by asking her English colleagues for further clarifications of terms used. In Tristana's case, her non-English accent was emphasized to exclude her, and she had to use her own resolve to "claim ground", by "acting silly", by seeking information on nurse specializations through the NMC and employment in the local National Health Service (NHS) hospital and also by using the local leisure facilities with her English partner. Acculturation stress, in internalizing othering practices and managing complex belongings, was temporarily resolved through "claiming ground", while she made plans to work for a local NHS hospital and leave the private care sector.

\section{"I am dark, and I hate it and when I actually know that I am starting to sound}

\section{like them"-Bonnie's case}

We now focus on Bonnie's case. Bonnie is a Filipino senior nurse, employed by a private care home company in Community A. We met Bonnie after she had been living in Community A for six years. She migrated from the Philippines in 2002, her elder sister working for the same company at the time but later employed at the local NHS hospital. She sought to send remittances to family in the Philippines but also to improve her 
professional skills. For Bonnie, "being othered" and expected to "blend in" were especially painful:

We have a really, really high respect for our elderly - our parents, our sisters who are older than us. So, in a way that created a sort of like passiveness among us all with regards to our bosses as well - our superiors, our supervisors or whatever you call it. ... We take the beatings and we were all so petrified, we were all so frightened of "them" if you will - so it was actually entirely different here because you can address somebody like if you're the manager, it's a first name basis. And it's not like that over there. [...] I think I will, I will always find a little difficulty trying to separate that all the time, 'cause my old upbringing and the way I was, there in the Philippines, will always get in the way. [...] It's quite disrespectful to actually just call your professors or teachers on the first names... Otherwise, you-you're different, you don't blend in with everybody... Although it's nice - it took us time to actually get used to it and address people in the first name. It's still very much in my system no matter how I cleanse myself / Even if we can speak English, they [locals] go like this, if our accent is American and they go, even if it's a simple word, they, I think it's the intonation if you know what I mean. And they go, OK, and then I have to switch, I'll sort of like tweak it and make it sound like it's a [local] accent and they all understand me... and I hated it, I said, "I've lost, I've lost my American accent now", but I am really pleased with Edilene she really maintained it. Because I think I am dark, you see, I am dark, and I hate it and when I actually know that I am starting to sound like them and then I start like sort of retreat back to my, oh my goodness...

During her first interview, Bonnie offered a detailed narration on the issue of "respect" and "passiveness" and how working in an English care home offers opportunities to "be yourself". The number of statements with either an "Orientation" or "Evaluation" character (Labov \& Waletzky, 2003; Labov, 2010) reflect the importance of "respect" and being treated as an “equal”. Bonnie's narration is full of metaphors (Mishler, 1999), such as "petrified" and "cleanse myself". There is also a number of "dramaturgical" elements (Riessman, 2000), for example "take the beatings", emphasizing her ability to endure. By having a more equal relationship with management, she is "claiming ground" 
in the workplace environment. To do so, she has to "blend in with everybody", but first she has to "cleanse" herself, a difficult task as her "upbringing" is "still very much in [her] system". There is a sense of internal conflict, a need to feel respected which would, however, entail shedding integral parts of her ethnic identity.

During the third interview she provided an example of "being othered" for using her own American-English accent. This is an issue of considerable tension, as she needs to "tweak it" in order for the locals to understand her. Yet, she said, "I hate it... when I am starting to sound like them". There was fear/resistance of blending in too much. What set her apart was also her skin color, "I am dark", which she brought up repeatedly, emphasizing her feeling of being "different" in this "white", rural community. Her fear of losing her ethnic identity, 'I said "I've lost, I've lost my American accent now", caused her to compare herself with her co-ethnic colleague and housemate, Edilene. Their relationship took on the character of a "pure relationship", assisting her in the “reflexive project of the self" (Giddens, 1999, p. 186). Bonnie's internal tension of balancing these complex belongings caused her to "retreat back", without elaborating further, taking a "defensive identity" (Hall, 2003). With her narration she tried to reconciliate this "breach between real and ideal, self and society" (Riessman, 1993, p.3), that is, her real self and the self expected by others. Thus, trying to "be yourself" and "blend in" can challenging for those who need to "tweak" their accent to be understood and for whom difference, on the grounds of race, ethnicity and nationality, is an embodied experience. Acculturation stress here is palpable.

\section{Concluding remarks}

The rural migrant care workers, working for the private care sector, experienced "being othered" in their everyday lives and in many forms. The participants resisted these forms of exclusion, of discrimination and exploitation, by establishing local networks and using 
local services, and by reflecting on these experiences before taking further action. In each of these cases, different social positionings or social divisions (Yuval-Davis, 2006; 2011) were either highlighted, obscured, allowed access to certain resources or created further obstacles in their efforts to settle in these rural communities. Acculturation stress could not always be resolved or was resolved temporarily. The care homes as "critical locations" (Acker, 2006) perpetuated forms of inequality and exploitation, however, the wider rural setting was an important factor in the experiencing of oppression and acculturation stress. The migrant care workers, however, used their strategies of adaptation and resistance, "being othered" as a reflective account and "claiming ground" as a way of dealing with acculturation stress and resisting othering, in an effort to mitigate the effects of social divisions intersecting in the rural communities. By using an intersectionality framework (Acker, 2006; Anthias, 2013; Walby, 2011; Walby et al., 2012; Yuval-Davis, 2006; 2011) and acculturation as an analytical tool, we were able to examine migrant care workers' rural settlement and their own capacity and resources in dealing with institutional, organizational and other structural inequalities and how they sought to navigate such complexities and take purposeful action to deal with "othering" and social exclusion.

With projections of the number of older adults over the age of eighty five set to double by 2035 (Ives, 2018) and questions raised about the capacity of the existing social care model, already strained to cope, such challenges will increase the vulnerability of migrant care workers, EU and overseas. While our research highlights the importance of context, focusing on other geographical areas, also combining other methods, for example, focus groups (Litosseliti, 2007) and reflective diaries (Cuban, 2013), would allow scrutiny of oppression based on the intersection of other social divisions, such as sexuality and disability, not examined here. Therefore, in-depth analysis of acculturation 
stress, as accentuated and perpetuated by intersections of social divisions in rural settings, and migrant strategies of resistance and adaptation in managing normative and unattainable expectations of belonging to a "community of value" (Anderson, 2013), advance the areas of rural sociology and migration studies, also the study of acculturation and acculturation stress for migrant populations.

Acknowledgements

We would like to express gratitude to the participants of this study for their time and their invested trust, in helping us understand the challenges connected to settling in small, rural communities and their own resolve in overcoming these. We would also like to thank the two anonymous reviewers for their helpful comments.

References:

Acker, J. (2006). Inequality Regimes. Gender, Class, and Race in Organizations. Gender \& Society, 20(4), 441-464.

Aguinaldo, J.P. (2012). Qualitative analysis in gay men's health research: comparing thematic, critical discourse, and conversation analysis. Journal of Homosexuality, 59(6), 765-787.

Agyeman, J. \& Spooner, R. (1997). Ethnicity and the rural environment. In P. Cloke, \& J. Little (Eds.) Contested countryside cultures: otherness, marginalisation and rurality (pp. 197-217). London: Routledge.

Anderson, B. (2013). Us \& Them? The Dangerous Politics of Immigration Control. Oxford: Oxford University Press.

Anthias, F. (2013). Moving beyond the Janus face of integration and diversity discourses: towards an intersectional framing. The Sociological Review 61, 323-343.

Askins, K. (2009). Crossing divides: Ethnicity and rurality. Journal of Rural Studies 25 (4), 365-375.

Berry, J. (1997). Immigration, Acculturation, and Adaptation. Applied Psychology: An International Review, 46(1), 5-34. 
Berry, J. (2005). Acculturation: Living successfully in two cultures. International Journal of Intercultural Relations, 26, 697-712.

Berry, J. (2008). Globalization and acculturation. International Journal of Intercultural Relations, 32, 328-336.

Berry, J. (2009). A critique of critical acculturation. International Journal of Intercultural Relations, 33, 361-371.

Berry, J., \& Sabatier, C. (2011). Variations in the assessment of acculturation attitudes: Their relationships with psychological wellbeing. International Journal of Intercultural Relations 35, 658-669.

Bhatia, S. \& Ram, A. (2009). Theorizing identity in transnational and diaspora cultures: A critical approach to acculturation. International Journal of Intercultural Relations 33, 140-149.

Boyatzis, R.E. (1998). Transforming Qualitative Information - Thematic Analysis and Code Development. London: Sage Publications.

Buchan, J. (2009). Achieving workforce growth in UK nursing: Policy options and implications. Collegian 16: 3-9.

Cangiano, A., Shutes, I., Spencer, S., \& Leeson, G. (2009). Migrant Care Workers in Ageing Societies: Research Findings in the United Kingdom. Retrieved from COMPAS, ESRC Centre on Migration, Policy and Society, Oxford website: http://www.compas.ox.ac.uk/fileadmin/files/Publications/Research_projects/Lab our_markets/Migrant_care_workers/MCW\%20report\%20-\%20final\%20\%20website $\% 20$ version.pdf

Cangiano, A. \& Shutes, I. (2010). Ageing, Demand for Care and the Role of Migrant Care Workers in the UK. Population Ageing 3: 39-57.

Carling, J., Erdal, M.B., \& Ezzati, R., (2014). Beyond the insider-outsider divide in migration research. Migration Studies 2(1), 36-54.

Cloke, P. (2004). Rurality and racialised others: out of place in the countryside? In N. Chakraborti, \& J. Garland (Eds.) Rural Racism (pp. 17-35). Cullompton: Willan Publishing.

Cloke, P., \& Little, J. (1997). Introduction: Other Countrysides? In P. Cloke, \& J. Little (Eds.) Contested countryside cultures: otherness, marginalisation and rurality (pp. 1-18). London: Routledge. 
Cuban, S. (2013). Deskilling migrant women in the global care industry. Basingstoke: Palgrave Macmillan.

Datta, K., McIIwaine, C., Evans, Y., Herbert, J., May, J., \& Wills, J. (2006). Work and survival strategies among low-paid migrants in London. Retrieved from ESRC and Queen Mary, University of London website: http://citeseerx.ist.psu.edu/viewdoc/download?doi=10.1.1.544.440\&rep=rep1\&t ype $=$ pdf

de Lima, P. (2006). 'Let's keep our heads down and maybe the problem will go away': Experiences of rural minority ethnic households in Scotland. In S. Neal, \& J. Agyeman (Eds.) The new countryside? Ethnicity, nation and exclusion in contemporary rural Britain (pp. 73-98). University of Bristol: Policy Press.

Fortier, A.M. (2000). Migrant Belongings: Memory, Space, Identity. Oxford: Berg.

George, S. (2005). When Women Come First: Gender and Class in Transnational Migration. London: University of California Press.

Giddens, A. (1999). Modernity and Self-Identity: Self and Society in the Late Modern Age. Cambridge: Polity Press.

Hall, S. (1996). Introduction: Who needs 'identity'? In S. Hall, \& P. du Gay (Eds.) Questions of Cultural Identity (pp. 1-17). London: Sage Publications.

Hall, S. (2003). New Ethnicities. In L. Alcoff, \& E. Mendieta (Eds.) Identities: Race, Class, Gender and Nationality (pp. 90-95). Oxford: Blackwell Publishing.

Heyl, B.S. (2001). Ethnographic Interviewing. In P. Atkinson, A. Coffey, S. Delamont, J. Lofland, \& L. Lofland (Eds) Handbook of Ethnography (pp. 369-383). London: Sage Publications.

Jayaweera, H. (2015) Migrant workers in the UK healthsector (report), February 2015.

COMPAS, University of Oxford. Retrieved by: https://www.compas.ox.ac.uk/wp-content/uploads/PR-2015-WORKINTBackground-Report.pdf

Ives, L. (2018, August) Numbers of elderly in 24-hour care set to double by 2035. $B B C$ Health. Retrieved from: https://www.bbc.co.uk/news/health-45354846

Kingma, M. (2006). Nurses on the Move: Migration and the Global Health Care Economy. Ithaca: Cornell University Press. 
Labov, W. (1984). Intensity. In D. Schiffrin (Ed.) Meaning, Form and Use in Context: Linguistic Applications (pp.43-70). Washington DC: Georgetown University Press.

Labov, W. (2003). Uncovering the event structure of narrative. In D. Tannen \& J. Alatis (Eds.) Round Table on Languages and Linguistics 2001 - Linguistics and the Real World: Discourse and Beyond (pp.63-83). Washington DC: Georgetown University Press.

Labov. W. (2010). Oral narratives of personal experience. Retrieved from: http://www.ling.upenn.edu/ wlabov/Papers/FebOralNarPE.pdf

Labov, W., \& Waletzky, J. (2003). Narrative Analysis: Oral Versions of Personal Experience. In Paulston, C., \& Tucker, G. (Eds.) Sociolinguistics: The Essential Readings (pp. 74-104). Oxford: Blackwell Publishing.

Litosseliti, L. (2007). Using focus groups in research. London: Continuum.

McGregor, J. (2007). 'Joining the BBC (British Bottom Cleaners)': Zimbabwean Migrants and the UK Care Industry. Journal of Ethnic and Migration Studies $33(5), 801-824$.

Migration Observatory, (2012). Migrants in the UK: An Overview. University of Oxford, Retrieved from: http://migrationobservatory.ox.ac.uk/briefings/migrants-ukoverview

Mishler, E.G. (1986). Research Interviewing: Context and Narrative. London: Harvard University Press.

Mishler, E.G. (1990). Validation in Inquiry Guided Research: The Role of Exemplars in Narrative Studies. Harvard Educational Review 60(4), 415-442.

Mishler, E.G. (1999). Storylines: Craftartists' Narratives of Identity. London: Harvard University Press.

Murdoch, J. \& Pratt, A. (1997). From the power of topography to the topography of power: A discourse in strange ruralities. In P. Cloke, \& J. Little (Eds.) Contested countryside cultures: otherness, marginalisation and rurality (pp.51-69). London: Routledge.

Neal, S., \& Agyeman, J. (2006). Remaking English ruralities: processes of belonging and becoming, continuity and change in racialised spaces. In Neal, S., \& Agyeman, J. (Eds.) The new countryside? Ethnicity, nation and exclusion in contemporary rural Britain (pp.99-126). University of Bristol: Policy Press. 
Neal, S. \& Walters, S. (2006). Strangers asking strange questions? A methodological narrative of researching belonging and identity in English rural communities. Journal of Rural Studies 22, 177-189.

Nursing and Midwifery Council (NMC), (2017). Changes to language testing requirements come into force'. 1 November. Retrieved from: https://www.nmc.org.uk/news/news-and-updates/changes-to-language-testingrequirements-come-in-force/

Ochs, E., \& Capps, L. (1996). Narrating the Self. Review of Anthropology 25, 19-43.

Riessman, C.K. (1987). When Gender is Not Enough: Women interviewing Women. Gender and Society 1(2), 172-207.

Riessman, C.K. (1993). Narrative Analysis. London: Sage Publications.

Riessman, C.K. (2000). Analysis of Personal Narratives. Retrieved from: http://alumni.media.mit.edu/ brooks/storybiz/riessman.pdf

Skills for Care (2018) The state of the adult social care sector and workforce in England. Leeds: Skills for Care. Retrieved from: https://www.skillsforcare.org.uk/NMDS$\underline{\text { SC-intelligence/Workforce-intelligence/publications/The-state-of-the-adult- }}$ $\underline{\text { social-care-sector-and-workforce-in-England.aspx }}$

Solano, D., \& Rafferty, A.M. (2007). Can lessons be learned from history? The origins of the British imperial nurse labour market: A discussion paper. International Journal of Nursing Studies 44, 1055-1063.

Spiliopoulos, G., \& Timmons, S. (2019). 'How can the NHS recruit and retain migrant nurses after Brexit?', UoN Asia Research Institute Policy Brief Background Report, University of Nottingham. June 2019. Retrieved from: https://www.nottingham.ac.uk/asiaresearch/documents/policy-briefs/policyreport-spiliopoulos.pdf

Spiliopoulos, G. (forthcoming). 'Brexit uncertainties: Political rhetoric vs British core values in NHS'. In G. Rawnsley, Y. Ma, K. Pothong (Eds.) Handbook of Political Propaganda. Cheltenham: Edward Elgar Publishing.

Tolia-Kelly, D. (2007). Fear in Paradise: The Affective Registers of the English Lake District Landscape Re-visited. Senses and Society 2(3), 329-352.

Walby, S. (2011). Globalization and multiple inequalities. In E. Ngan-ling Chow, M.T. Segal, \& L. Tan (Eds.) Analyzing gender, intersectionality, and multiple 
inequalities: global, transnational and local contexts (pp.17-33). Bingley: Emerald Group Publishing Limited.

Walby, S., Armstrong, J., \& Strid, S. (2012). Intersectionality: Multiple Inequalities in Social Theory. Sociology 46(2), 224-240.

Weinreich, P. (2009). 'Enculturation', not 'acculturation': Conceptualising and assessing identity processes in migrant communities'. International Journal of Intercultural Relations 33, 124-139.

Yuval-Davis, N. (2006). Intersectionality and Feminist Politics. European Journal of Women's Studies 13(3), 193-209.

Yuval-Davis, N. (2011). The Politics of Belonging: Intersectional Contestations. London: Sage Publications. 